\title{
Effect of static magnetic field with quercetin and hesperetin on MCF-7 and MDA MB-231 breast cancer cells
}

\section{[Kuersetin ve Hesperetin ile Statik Manyetik Alanın MCF-7 ve MDA MB-231 Meme Kanseri Hücrelerine Etkisi]}

https://doi.org/10.1515/tjb-2019-0528

Received December 21, 2019; accepted June 13, 2020;

published online September 2, 2020

\section{Abstract}

Objectives: Static magnetic field (SMF) was previously in practice for the therapy of some diseases and it has been thought that it may be a reliable supportive technique. The aim of this study was to find out the synergistic effect of SMF administration with flavonoids in terms of apoptosis on breast cancer cell lines.

Material and methods: The effects of flavonoids on the proliferation of breast cancer cell lines were observed by MTT cell viability test. The cells were treated with $\mathrm{SMF}+$ hesperetin and SMF + quercetin. Apoptosis rates and Bax, Bcl-2 protein levels were detected by flow cytometer and Western Blot, respectively.

Results: Cell lines were treated with quercetin and quercetin + SMF, substantial amount of cells [3.96, 4.86, 11.40\% for MCF-7 and MDA MB-231 cell lines, respectively $(\mathrm{p}<0.001)]$ were mainly in the apoptotic phase. The apoptosis rates of hesperetin and hesperetin + SMF were 2.53, 6.06, 10.10\% $(\mathrm{p}<0.001)$ for MCF-7 and MDA MB231 cell lines, respectively. Bax:Bcl-2 ratios were

*Corresponding author: Gulsum Abusoglu, Department of Medical Laboratory Techniques, Selcuk University Vocational School of Health Sciences Medical Services and Techniques Institution, 42200 Konya, Turkey. Phone: +90 5418354647, Fax: +90 3322231094

E-mail: tekinglsm@gmail.com. https://orcid.org/0000-0003-16301257

Bahadir Ozturk, Department of Biochemistry, Selcuk University Faculty of Medicine, Konya, Turkey significantly increased after flavonoids + SMF exposure (2.7 vs. 1.6 fold $(\mathrm{p}<0.0001)$ in hesperetin + SMF group and 1.8 vs. 1.3 -fold $(\mathrm{p}<0.0001)$ in quercetin + SMF group for MCF-7 and MDA MB-231 cell lines, respectively.

Conclusions: SMF might support the anti-cancer properties of flavonoids, on breast cancer cells via mitochondriarelated apoptosis pathway.

Keywords: apoptosis; flavonoid; MCF-7; MDA MB-231; static magnetic fields.

öz

Amaç: Statik manyetik alan (SMA) daha önce bazı hastalıkların tedavisi için bir uygulama alanıydı ve güvenilir destekleyici tedavi tekniği olabileceği düşünülmekteydi. $\mathrm{Bu}$ çalışmanın amacı, flavonoidlerle beraber SMA uygulamasının meme kanseri hücre serilerinin apopitoz üzerindeki sinerjistik etkisini bulmaktır.

Gereç ve Yöntemler: Flavonoidlerin meme kanseri hücre serilerinin proliferasyonu üzerindeki etkileri MTT hücre canlılık testi ile gözlenmiştir. Hücreler SMA + hesperetin ve SMA + kuersetin ile muamele edilmiştir. Apopitoz oranı ve Bax, Bcl-2 protein seviyeleri sırasıyla akış sitometresi ve Western Blot ile tespit edilmiştir.

Bulgular: Hücre hatları quercetin ve quercetin + SMF ile tedavi edildi, esasen önemli miktarda hücre [sırasıyla MCF7 ve MDA MB-231 hücre hatları için \% 3.96, \% 4.86 ve $\%$ 9.70, \% 11.40 ( $\mathrm{p}<0.001)]$ apoptotik fazdaydı. Hesperetin ve hesperetin + SMF'nin apopitoz oranlar1 MCF-7 ve MDA MB-231 hücre hatları için sırasıyla $\% 2.53, \% 6.06$ ve $\%$ 4.66, $\% \quad 10.10 \quad(\mathrm{p}<0.001) \quad$ idi. Bax:Bcl-2 oranlar1 flavonoidler + SMF maruziyetinden sonra sirasıyla MCF-7 ve 
MDA MB-231 hücrelerinde hesperetin + SMF grubunda 2.7' ye kıyasla 1.6 kat $(\mathrm{p}<0.0001)$ ve quercetin + SMF grubunda 1.8 'e kiyasla 1.3 kat $(\mathrm{p}<0.0001)$ idi.

Sonuç: SMA, meme kanseri hücreleri üzerinde flavonoidlerin mitokondri ile ilişkili apoptoz yolu aracılığıyla anti-kanser özelliklerini destekleyebilir.

Anahtar Kelimeler: Flavonoid; MCF-7; MDA MB-231; Statik Manyetik Alan; Apopitozis.

\section{Introduction}

Flavonoids are small, natural compounds found in plants and many nutritional products. They establish the basic content of citrus fruits and frequently consumed in several regions as a part of diet. Flavonoids are considered to be protective against some disorders such as cardiovascular and inflammatory diseases, cancer especially via stimulation of apoptosis, blockade of proliferation and alteration of oxidative stress balance in different tumour cells [1-4].

Hesperetin (3',5,7-Trihydroxy-4'-methoxyflavanone) (Hes) (Figure 1A), a member of the flavanone subfamily of flavonoids, is a derivative of hesperidin that exists in citrus fruits such as oranges and grapefruit [5]. Citrus fruits are commonly found in Mediterranean region countries, such as Turkey. A protective property of the Mediterranean diet on breast cancer is biologically reasonable since the Mediterranean diet characteristics are based on high content of fibre and antioxidants, such as flavonoids, vitamins, carotenoids and squalene (basicly from virgin olive oil). These compounds may alter the risk of breast cancer via diminishing naturally occurring estrogens, elevating sexhormone binding globulin concentrations, scavenging free radicals, counteracting with DNA damage and decreasing oxidative stress [6] over the past decade, several studies were designed to find out the molecular pathways and possible mechanisms of Hes. These molecules present familiar and unique anti-tumour, anti-inflammatory, neuroprotective, and antioxidant qualifications [7] Hes was demonstrated to have disincentive effects on cancers via affecting estrogen or testosterone receptors [8] These polyphenolic compounds were found to suppress the production of aromatase enzyme and proliferation of breast cancer cells in culture medium due to antiestrogenic properties [2-4].

Quercetin (3,3', $4^{\prime}, 5,7$-pentahidroksiflavon) (Figure 1B) a member of polyphenolic flavonoids, is one of the most featured dietary antioxidants and includes a huge number of flavonoids [3,9]. It is predominantly found in several vegetables and fruits such as apple, onion, red wine, grapefruit, black tea, raspberries, blueberries and cherries [1]. The data of many in vitro studies have presented $\mathrm{Qu}$ as a familiar effective antioxidant [10]. Nowadays, it has been promosed that antioxidant properties of $\mathrm{Qu}$ could mediate to cancer chemotherapy and the supression of tumor growth [3]. Also, Hes was suggested to be a strong radical neutralizer and to assist cellular antioxidant defenserelated enzyme activity.

In recent years, many in vivo and in vitro researches have defined the biophysical and biochemical effects of magnetic fields [11-33]. Magnetic fields therapy (magnetotherapy) permits a confidential, laborless and noninvasive method to cure the region of damage, source of pain, inflammation, disorders and diseases and to effect on proteins, ions and metals via familiar physical pathways within the cells [12]. Nevertheless, magnetotherapy have been concluded to alter cancer cell biology both in vitro and in vivo $[13,15,16,17]$. Although, some molecular pathways are suggested for the effect of SMF on various cellular functions; exact mechanisms are unknown yet [18].

In contrast to these studies, SMF exposure was not accepted as monotherapy, it was recommended as an adjuvant therapy $[13,19]$. In this regard, the synergistic effect of anticancer drugs with the magnetic field can be considered as an alternative, complementary therapy protocol [13]. While possible side effects of antineoplastic drugs used in classical therapy of cancer are also considered, the herbal flavonoids can be used therapeutically as an alternative to these medicines in order to minimize or completely eliminate side effects of antineoplastic drugs. This might be evaluated as a new and efficient treatment strategy for cancer. Nevertheless, the synergistic mechanism between the magnetic field and the flavonoids is unclear. Combinational effect of SMF and flavonoids was based on elevation of binding capacity of capsaicin for the TRPV1 channel on HepG-2 cells [20]. It was suggested that treatment with vitamin D and SMF may provide advantage for chemoprevention or curation of breast cancer [21]. Static magnetic field, alone or with other agents, seems not to present an influential alternative for breast cancer treatment. In our best knowledge, there is no study comparing the synergistic effect of SMF and flavonoids in breast cancer. The hypothesis of current study was to find out the possible effect of SMF on proliferation and cell death with combination of two flavonoids. In this study, our aim was to investigate the synergistic effect between SMF and administration of antiproliferative flavonoids on apoptosis and protein expressions on breast cancer cell lines. 
<smiles>COc1ccc([C@H]2CC(=O)c3c(O)cc(O)cc3O2)cc1O</smiles><smiles>O=c1c(O)c(-c2ccc(O)c(O)c2)oc2cc(O)cc(O)c12</smiles>
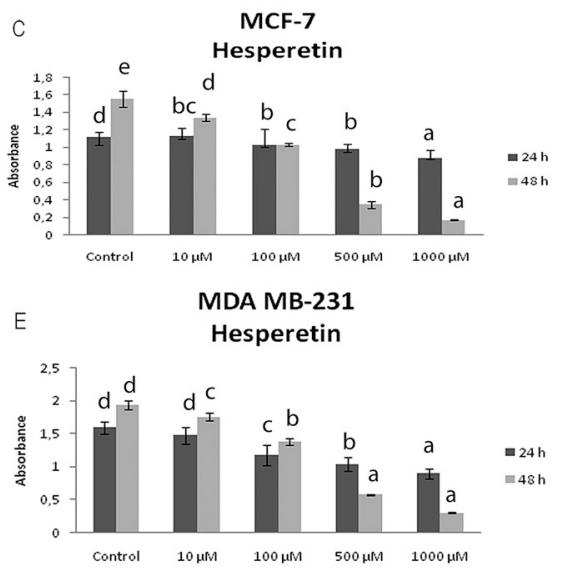

\section{Materials and methods}

\section{Chemicals and reagents}

Dulbecco's Modified Eagle Medium (DMEM), Fetal Bovine Serum (FBS), L-glutamine, Penicillin-streptomycin, Trypan blue, Phosphate Buffer Saline (PBS) and trypsin were purchased from Biological Industries Kibutz Haemek, Israel. Hes, Qu and dimethyl sulphoxide (DMSO) were from Sigma-Aldrich Inc., St. Louis,USA. Bax, Bcl-2 and $\beta$-Actin were purchased from Novus Biologicals, MTT assay kit was purchased from Cayman. FITC Annexin V/PI and Western Breeze Cromogenic Immuno Detection System were purchased from Invitrogen, Bicinchoninic acid (BCA) Protein analysis kit was purchased from Thermo Fisher Scientific.

\section{Experimental design and groups}

For apoptosis and Western blot analyses, the applications were divided into six groups; Group I: Negative control group (without SMF treatment but all experimental conditions were identical); Group II: SMF administration group (SMF-exposed group, cells were consistently exposed to only SMF for $48 \mathrm{~h}(174 \mathrm{mT})$ ); Group III: Hes group (cells were incubated with only $\mathrm{IC}_{50}$ of Hes for $48 \mathrm{~h}$ ); Group IV: SMF + Hes group (Cells were exposed with both SMF and IC So $_{5}$ of Hes treatment for $48 \mathrm{~h}$ ); Group V: Qu group (cells were incubated with only $\mathrm{IC}_{50}$ of $\mathrm{Qu}$ for $48 \mathrm{~h}$ ); Group VI: SMF + Qu group (Cells were exposed with both SMF and $\mathrm{IC}_{50}$ of Qu treatment for $48 \mathrm{~h}$ ). In brief, MCF-7 and MDA MB-231 cells $\left(1 \times 10^{6}\right.$ cells) were adhered overnight in Petri dishes $\left(100 \mathrm{~cm}^{2}\right)$ and incubated with flavonoids and exposed with SMF.

\section{Cell cultures}

Human breast carcinoma MDA MB-231 (ATCC® HTB-26 ${ }^{\mathrm{TM}}$ ) and MCF7 cells (ATCC $\left(\right.$ HTB-22 $2^{\mathrm{TM}}$ ) were cultured in DMEM fed with $1 \%$ penicillin-streptomycin and $10 \% \mathrm{FBS}$ and incubated at $37{ }^{\circ} \mathrm{C}$ in a humidified atmosphere with $5 \% \mathrm{CO}_{2}$. The cells were then trypsinized (0.025\% trypsin, $0.02 \%$ EDTA) after they were cultivated till 70-80\% confluent. Third or fourth passages of cells with $70-80 \%$ confluency were used for therapeutic experiments.

\section{Cell viability assays}

MTT assay was conducted to find out antitumor capacity of Hes and Qu on MCF-7 and MDA MB-231 cells. Briefly, cells were cultured at 10.000 cells/well in 96 -well culture plates to $~ 75 \%$ confluency culture plates before the desired treatment and treated with Hes and Qu at various concentrations $(10,100,500$ and $1000 \mu \mathrm{M})$ for 24 and $48 \mathrm{~h}$. Cells were then labeled with MTT and the formazan product was dissolved with DMSO. The absorbance values were obtained at $540 \mathrm{~nm}$. The half maximal inhibitory concentration $\left(\mathrm{IC}_{50}\right.$ (defines the amount of a compound necessary to exclude $50 \%$ of species exposed to it in any types of toxicological test)) values are calculated.

\section{SMF design and application}

An exposure system was designed to treat cells with SMF under tightly controlled electromagnetic and environmental circumstances. $250 \mathrm{~mm}$ width, $50 \mathrm{~mm}$ height and $10 \mathrm{~mm}$ length neodymium-ironboron (Ne-Fe-B) elements were used and the permanent magnets have been purchased from those available on the magnet market. The two iron dishes were positioned in the middle $(1 \mathrm{~cm}$ thickness, $5 \mathrm{~cm}$ in diameter) far away $3 \mathrm{~cm}$ between both, permitting disposal of a Petri dish in between two iron dishes. The magnetic circle was triggered as an iron constitution, while two dishes of the similar item, fitted between the magnets, was evaluated which permit to elevate the area constancy in the specimen status. Density of the field produced by the magnet was controlled via digital Gm (AC/DC Magnetic Meter PCE-MFM 3,000) and the Petri dishes were placed constant to achieve 
the same effect of the magnetic field. The magnetic triggering grade was checked for the different areas between the iron dishes. The temperature was controlled and recorded by a thermometer to maintain the optimal conditions for the magnetic area. The magnetic triggering grade in the sample region was recorded and found as $174 \mathrm{mT}$. The magnetic field value was not changed during the experiment period because iron tablets were fixed. SMF was applied permanently for up to $48 \mathrm{~h}$.

\section{Apoptosis analyses}

The apoptosis was determined by flow cytometer with Annexin V-FITC (fluorescein isothiocyanate) and PI (Propidium Iodide) staining tool to separate early apoptotic from necrotic cells. By synchronically staining cells with annexin V-FITC and PI, it was likely to differentiate viable cells (Q3; Annexin V FITC (-), PI (-)), early apoptotic cells (Q4; Annexin V FITC (+), PI (-)), and late apoptotic (Q2; Annexin V FITC (+), PI $(+))$. The experimental groups were exposed with different treatment combinations and stained with $10 \mu \mathrm{l}$ Annexin V and $10 \mathrm{ul} \mathrm{PI,}$ stored at closed place for $20 \mathrm{~min}$ at room temperature and analyzed after addition of $500 \mu \mathrm{L}$ of binding buffer. 10.000 cells per sample were picked up. The number of cells was presented as percentage for the Q1, Q2, Q3 and Q4. Total apoptotic cells percentages were calculated by addition of Q2 and Q4 phases.

\section{Western blot analyses}

The cells were harvested following $48 \mathrm{~h}$ of treatment, re-suspended in a lysis buffer and centrifuged at $12,000 \times \mathrm{g}$ for $10 \mathrm{~min}$. Protein levels were analyzed via BCA assay kit. Similar equivalents of protein $(20 \mu \mathrm{g})$ were re-suspended in Laemmle buffer, extracted by SDS-PAGE (12$15 \%$ gel) and taken onto nitrocellulose membranes. Membranes were exposed to blocking solution for $30 \mathrm{~min}$ at room temperature and afterwards stored for a night at $4^{\circ} \mathrm{C}$ with primary antibodies [Bcl-2 (1:1000), Bax (1:1000) and $\beta$-Actin (1:1000)]. After three times washing step, the membranes were treated with secondary antibodies (alkaline phosphatase, 1:1000) at room temperature for $1 \mathrm{~h}$. Immunoreactive bands were determined via chromogenic reagent. The bands of bound antibodies were analyzed and quantified by imaging device (Bio Rad $\mathrm{Gel}^{\mathrm{TM}} \mathrm{Doc}^{+}$). Data were obtained as the relative amount of the protein, normalized to $\beta$-Actin. Western blot analysis was performed to find out the ratio of Bax:Bcl-2, as this is characteristically suggested to be a predominant determinant for regulation of the apoptotic signal transduction cascade. The flavonoids + SMF treatment of cells led to a diminishment in $\mathrm{Bcl}-2$ production, with an accompanying elevation in the protein levels of Bax leading to a distinct elevation in the Bax:Bcl-2 ratio, which confirms apoptosis.

\section{Statistical analysis}

Statistical analysis was performed by SPSS 21.0 statistical program (SPSS, Inc., Chicago, IL, USA). Mean \pm SD (standard deviation) was used for all biological variables in graphs. Post-hoc Tukey analysis was applied for multiple comparison tests for estimating the SMF and flavonoid-induced cytotoxicity ratios, which were suggested as independent parameters. The experiments were performed at least three times. p-value less than 0.05 were accepted as statistically significant.

\section{Results}

\section{Effects of flavonoids on the viability of tumor cells}

MTT assay was conducted to find out the viability of MCF-7 and MDA MB-231 cells following the exposure with Hes and $\mathrm{Qu}$ at different levels during $48 \mathrm{~h}$. The flavonoids exhibited a possible cytotoxic property in MCF-7 (Figure 1C, D) and MDA MB-231 (Figure 1E, F), cells, particularly in cells that were exposed for $48 \mathrm{~h}$

The amount of Hes and Qu necessary for a 50\% inhibition of cell growth $\left(\mathrm{IC}_{50}\right)$ was calculated from dose response curve via several concentrations of the flavonoids. As presented Table 1; $\mathrm{IC}_{50}$ values of Hes and Qu were 87 and $155 \mu \mathrm{M}$; 129 and $174 \mu \mathrm{M}$ for MCF-7 and MDA MB-231, respectively.

The results stated that percent of viability declined in both cells with time duration and concentration.

\section{Flavonoids and SMF induced apoptosis in breast cancer cells}

Evaluation of apoptosis was performed with flow cytometer (BD FACSCanto ${ }^{\mathrm{TM}}$ ) via Annexin V-FITC and PI labeling, and the rate of apoptotic cells was estimated from the ratio of the sum of early plus late apoptotic cells at $48 \mathrm{~h}$ of treatment. As presented in Figure 2A, when MCF-7 cells were treated with $\mathrm{Qu}$ and $\mathrm{Qu}+\mathrm{SMF}$ for $48 \mathrm{~h}$, a substantial number of cells $(3.96 ; 4.86 \%$ respectively, $\mathrm{p}<0.001$ vs. control) was mainly in the apoptosis phase. A much more elevation in Hes and Hes + SMF resulted with an increase in apoptotic cell rates as $2.53 ; 6.06 \%$ for $48 \mathrm{~h}$ ( $\mathrm{p}<0.001$ vs. control), respectively. As presented in Figure 2B, when MDA MB-231 cells were exposed with Qu and $\mathrm{Qu}+\mathrm{SMF}$ for $48 \mathrm{~h}$, a considerable amount of cells (9.70; $11.4 \%$ respectively, $p<0.001$ vs. control) was mainly in the apoptosis phase. A further elevation in Hes + SMF resulted with an increase in apoptotic cell rates as 4.66; $10.1 \%$ for $48 \mathrm{~h} \quad(\mathrm{p}<0.001$ vs. control), respectively (Figure 2C).

Table 1: IC ${ }_{50}$ values for distinct MCF-7 and MDA MB-231 cells treated with flavanoids $(\mu \mathrm{M})$.

\begin{tabular}{lrr}
\hline & MCF-7 & MDA MB-231 \\
\hline Hesperetin $\left(I C_{50}\right),(\mu \mathrm{M})$ & 87 & 129 \\
Quercetin $\left(I C_{50}\right),(\mu \mathrm{M})$ & 155 & 174 \\
\hline
\end{tabular}




\section{Effect of SMF and flavonoids on the expression of $\mathrm{Bax}$ and $\mathrm{BCl}-2$ proteins}

Effects of the flavonoids + SMF on the Bax and Bcl-2 expressions at $48 \mathrm{~h}$ in both cell lines were represented in Western blot (Figure 3A, B). Relative Bax,Bcl-2 protein levels and Bax:Bcl-2 ratio were given in (Figure 3C-E, respectively). Bax:Bcl-2 ratios which favors apoptosis increased significantly after flavonoids + SMF exposure of both cell lines and so, 2.7 vs. 1.6 fold $(\mathrm{p}<0.0001)$ on Hes + SMF group and 1.8 vs. 1.3-fold $(\mathrm{p}<0.0001)$ on $\mathrm{Qu}+$ SMF group for MCF-7 and MDA MB-231 cell lines, respectively.

\section{Discussion}

The effect of SMF on cell growth and interactions of SMF with anti-cancer agents are in still debate. According to published studies, SMF was presented to change protein expression, apoptosis and proliferation in cancer cells [13, $14,16,17]$. Although the results from the scientific studies lead to some contradictions about the impact of SMF on tumor cells, it was reported that SMF as single treatment option is not adequately withstanding. The synergistic properties with chemotherapeutic agents were mentioned. In our study, SMF exposure increased the apoptotic cell rates in MCF-7 and MDA MB231 cell lines. SMF administration may reduce the levels of calcium ion via affecting either the characteristics of $\mathrm{Ca}^{2+}$-ATPase or altering the role of $\mathrm{Ca}^{2+}$ binding protein and the ion specific pores [22-24]. This hypothesis would mainly define all of the biological properties such as the regulation of apoptosis [25], proliferation and cell viability [26]. Other potential mechanisms of SMF that cause disorganization of the apoptotic rate such as modulation of the gene expressions, production $[17,24]$ or increase of oxygen free radicals were also significant. It is familiar that free radicals are intermediary molecules of apoptosis and via this way changes proliferation rate and viability [27]. However, how SMF alters apoptosis signaling cascade is still a debate.

It was reported that apoptotic cell rates increased by SMF administration on MCF-7 cells [28]. Several researches have pointed out the cytotoxic properties of SMF, which presents the different impacts that are specific to each cell type. Literature data about healthy cells as well as fibroblast [29] and lymphocyte [22] and cancer cells such as
A MCF-7/CONTROL

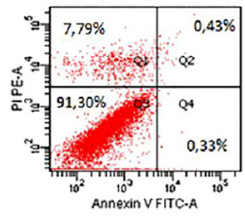

MCF-7/HESPERETIN
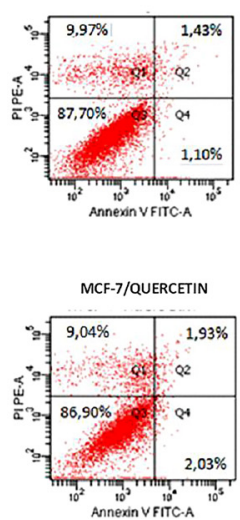

MCF-7/SMF

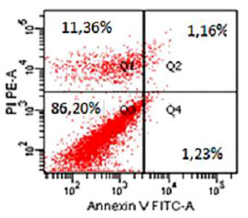

MCF-7/HESPERETIN+SMF

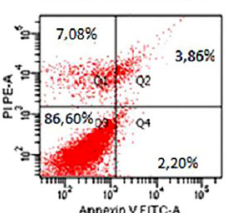

MCF-7/QUERCETIN+SMF

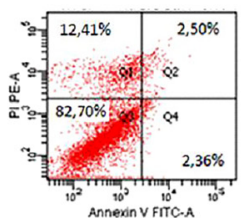

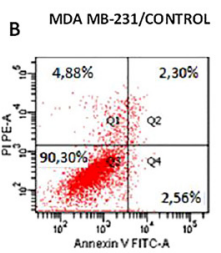

MDA MB-231/HESPERETIN

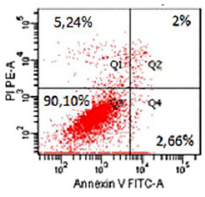

MDA MB-231/QUERCETIN

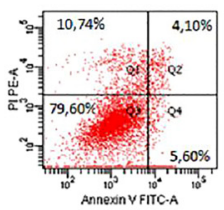

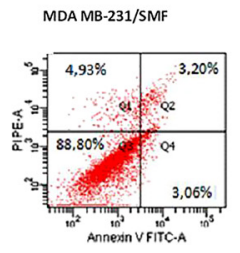

MDA MB-231/HESPERETIN+SMF

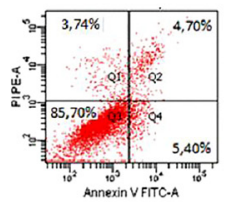

MDAMB-231/QUERCETIN+SMF

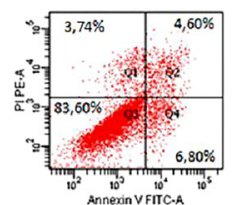

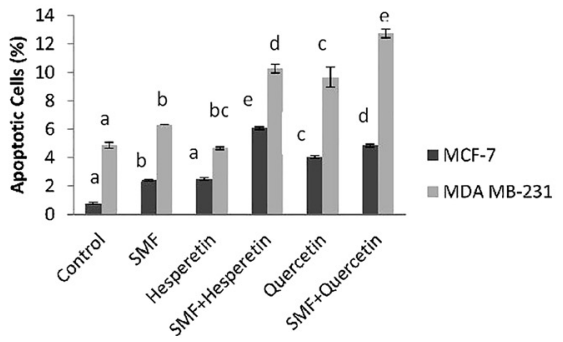

Figure 2: Analysis of flavanoids-induced apoptosis in breast cancer cells using the Annexin V-fluorescein isothiocyanate/propidium iodide (FITC-A/PI) staining assay. Cells were exposed with IC 50 of flavanoids and SMF (174 mT) for 48 h. MCF-7 (A); MDA MB-231 (B); Apoptotic cell rates (\%) of breast cancer cells was calculated after incubation with IC 50 of flavanoids and SMF (174 mT) for $48 \mathrm{~h}(\mathrm{C})$. Each image has four quadrants: Q1, necrotic cells; Q2, late and Q4, early apoptotic cells, Q3, viable cells. Results were given as the Mean \pm Standard Deviation $(n=3 ; p<0.001$ vs. control) of three independent experiments. MCF-7 and MDA MB-231 cells were presented with dark and light colors, respectively. a, b, c, d, e letters; Significant differences between unexposed and exposed cells, post-hoc Tukey HSD multiple comparison tests. SMF: Static Magnetic Field. 
C
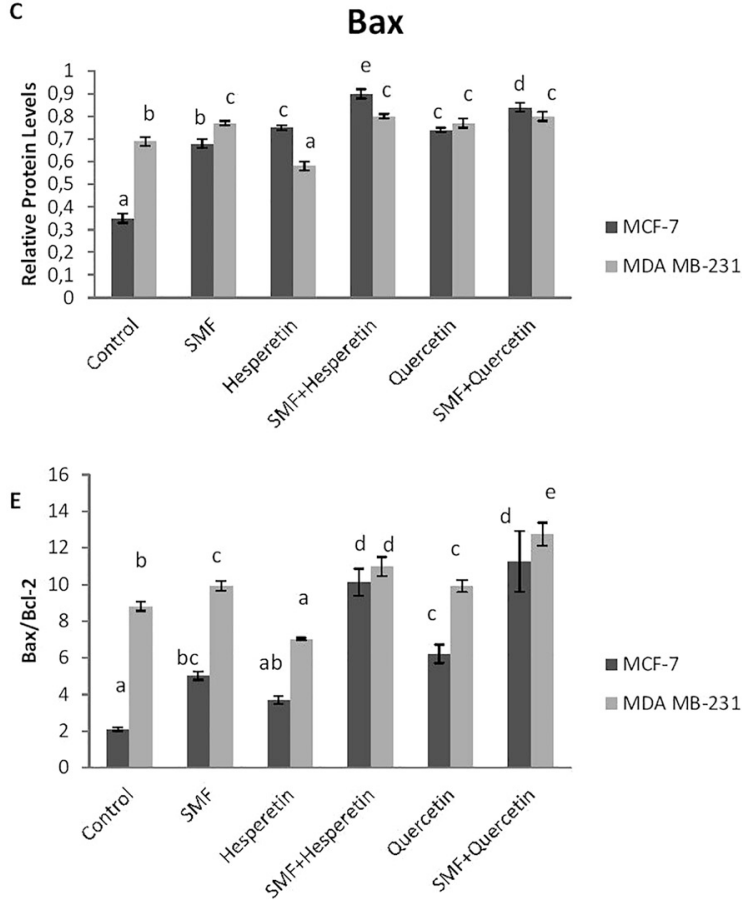

MCF-7

MDA MB-231
D

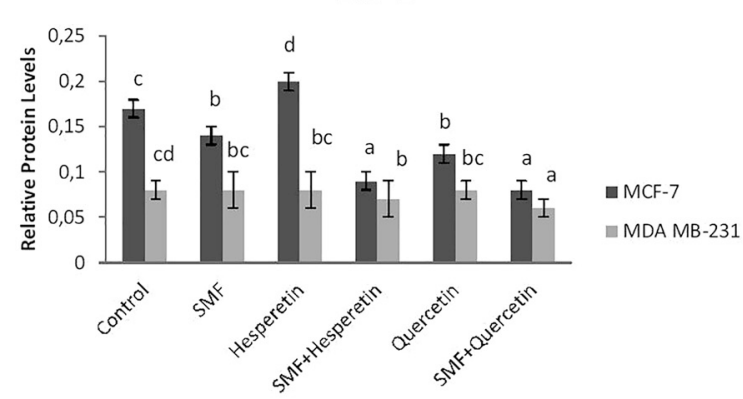

A

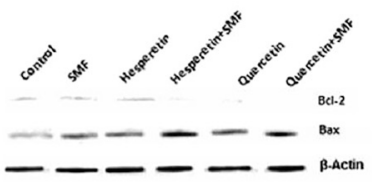

B

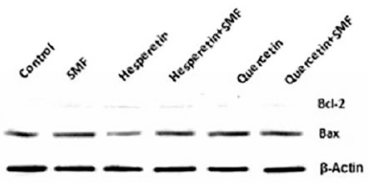

Figure 3: Protein expression of $\mathrm{Bax}$ and $\mathrm{Bcl}-2$ in breast cancer cells, analyzed with Western blotting (A: MCF-7; $\mathrm{B}$ : MDA MB-231). $\beta$-Actin was applied for normalization. The breast cancer cells were exposed with $\mathrm{IC}_{50}$ of flavonoids and SMF (174 mT) for $48 \mathrm{~h}$. Relative Bax protein levels (C); Relative Bcl-2 protein levels (D); Bax:Bcl-2 ratios of cells (E). MCF-7 and MDA MB-231 cells were presented with dark and light colors, respectively. Results were given as the Mean \pm Standard Deviation ( $n=3 ; p<0.0001$ vs. control). Letters (a, b, c, d, e); Significant differences between unexposed and exposed cells, by post-hoc Tukey HSD multiple comparison tests. SMF: Static Magnetic Field.

leukemia cells [30, 31] reported that SMF did not present any effect on cellular proliferation and structure. In contradiction, some investigators have stated the possible effects of SMF may alter cell growth [32, 33]. Many methodological differences have led to inconsistent results in SMF studies including; cell morphology, concentration of SMF and time of exposure, source of SMF, the drugs used with SMF etc. Therefore, the methodological variation is important in SMF studies. Magnetic fields with low doses were demonstrated to have important properties on cancer cells and patients [12]. The possible reason was that moderate induction doses were used to find out the biological properties of non-uniform SMF (174 mT) [1].

In this study, SMF, Hes, Qu monotheraphy elevated the Bax:Bcl-2 ratio in MCF-7 cell lines. Although SMF and Qu monotheraphy increased this ratio, Hes had no beneficial effect on MDA MB-231 cells (Figure 3E).

In this study, while the application of Qu increased apoptosis at a higher rate in both MCF-7 cells compared to both Hes and SMF, the efficacy of Qu on apoptosis in MDA MB-231 did not significantly differ from SMF application. But in MDA MB-231 cells, Qu stimulated apoptosis at a higher rate compared to Hes. The explanation might be due to that MDA MB-231 cell line is a receptor negative and more aggressive cell line compared to MCF-7. Qu seems to be much more potent cytotoxic agent compared to Hes. The cytotoxic property relies on commonly on the quantity and location of hydroxyl and methoxyl groups. The existence of C2-C3 double bond, a 4-carbonyl-group and orthopositional hydroxylation in the $B$ ring might be related with elevated cytotoxicity (Figure 1A, B). Additionally, O-methylation and glucuronidation may also change the cytotoxic properties of flavonoids [34]. Qu may be a stronger cytotoxic and antioxidant flavonoid than Hes due to its structural features.

It was suggested that Hes administration led to apoptosis on MCF-7 cells via cell cycle blockade [4]. Hes administration presented a dose- and time-related reduction in Bcl-2 protein expressions and elevation in Bax expression in MCF-7 cells [2]. In MCF-7 cells, Hes might induce apoptotic events such as phosphatidyl-serine externalization, DNA fragmentation, caspase-7 activation, and PARP (Poly (ADP-ribose)polymerase) cleavage, which are related with the induction of caspase-9, lack of mitochondrial membrane potential, efflux of cytochrome c, and an elevated Bax:Bcl-2 ratio [35].

It was suggested that $\mathrm{Qu}$ administration elevated amplitude of the pro-apoptotic protein Bax levels and 
diminished the concentrations of anti-apoptotic protein Bcl-2 on MDA MB-231 cells [1]. Treatment with Qu elevated the Bax expressions but reduced Bcl-2 expressions on MDA MB-453 [3].

$\mathrm{Qu}$ might mediate alteration of apoptosis by straight activation of the caspase pathway and via induction of mitochondrial cascade. Qu administration might alter cellular-signaling molecules related with apoptosis such as NF-k $\beta$ and Cox-2; blockade Bcl-xL and Bcl-2 anti-apoptotic proteins and upregulate Bax and several proapoptotic molecules [36].

Also, secondary outcome of this study was to specify that whether $\mathrm{Qu}+\mathrm{SMF}$ administration may have a superior pro-apoptotic property and synergistic effect compared to Hes + SMF in both cancer cells. Also the elevations of apopitotic cells were detected for both SMF + Hes and SMF + Qu compared to Hes and $\mathrm{Qu}$ administration (Figure 2). It has been reported that apoptotic pathway is modulated via both pro-apoptotic and anti-apoptotic proteins. The interaction of the apoptosis-triggering protein Bax and apoptosis- protein Bcl-2 distinctively checks the apoptotic signaling properties via modulation of mitochondrial cascade [20]. Bax:Bcl-2 ratios of cells demonstrated a significant increase in this study. The application of SMF in combination with flavonoids in both cell types increased the apoptosis by elevating the Bax:Bcl-2 ratio (Figure 3E).

Since anti-proliferative effects of flavonoids have been presented in several cancer cell types, the induction of possible effects of flavonoids after SMF exposure in breast cancer cell lines was found out in this study. It has been reported that apoptosis is a critical step for chemotherapyinduced tumor cell death [20].

In comparison to the monotherapy of SMF or flavonoids, the synergistic theraphy revealed higher ratios of apoptosis and Bax:Bcl-2 in tumor growth. Elevated Bax:Bcl-2 ratio in the flavonoid-treated group was enhanced via SMF effect. Based on these findings, it was suggested that $\mathrm{Qu}+\mathrm{SMF}$ administration increased the Bax:Bcl-2 levels and this polyphenol elevation was found to be statistically more important in both cell lines compared to Hes administration. $\mathrm{Qu}+\mathrm{SMF}$ administration were reported to have a superior pro-apoptotic property in terms of synergistic effect, revealing that it may be more efficient in breast cancer theraphy. Compositionally, polyphenols include aromatic rings which are equipped with one or more hydroxyl groups. The $\mathrm{OH}$ group on $\mathrm{C}-3$, configurational rearrangement of $\mathrm{B}$ ring and methoxyl group on Hes molecule distinguishes the structural property between Hes and Qu. Due to structural difference of these two flavonoids, the additional hydroxyl group on C-3 might promote to the downregulation of aromatase expression. Besides that, attachment point of the B-ring may also be important [37]. So, this positional rearrangement (Figure 1A, B) of $\mathrm{Qu}$ by containing two hydroxyl groups compared to Hes may offer an advantage. In the case of that hydroxyl groups which are present in flavonoids may contribute to antoxidant or antiproliferative unique features of these molecules.

Moreover, our results are coherent with the findings of studies on cancer cells $[13,19,38]$ presenting that cell death is related with the combination of SMF with the experimental agent. In this study, apoptosis might be accomplished via mitochondrial pathway (Bax:Bcl-2). SMF + flavonoids incubation significantly presented the origination of mitochondrial injury. In past decades, there has been a novel field of cancer hindering and treatment based on natural ingredients, particularly the external compounds due to their low toxicity and strong effectiveness [20].The mitochondrial cascade of apoptosis was recognized to be a fundamental pathway for the breast cancer cells while they were exposed with phenolic compounds [39]. The protective effect of the SMF + flavonoid administration ascertained in this study is coherent with other reports that suggest protection against drug-induced apoptosis in several cell lines and primary cultures [24] and many types of cells [13, 15].

In conclusion this study is the leading one that models SMF administration with dietary flavonoids on anti-cancer therapy, which ensure additional information about interaction between SMF and anti-cancer drugs and leads to improvement of new options against cancer treatment with lower cytotoxicity and side effects. Further studies should be designed to clarify the exact function of SMF and find out the optimal SMF parameters, convenient drug or phenolic compounds combinations. The biological and biophysical functions of the SMF application cannot be clearly demonstrated, it was demonstrated that various combined applications can be used to reduce the resistance and increase the effect of the anticancer phenolic compounds which were used solely. In this regard, the synergistic effect of anticancer compounds with the magnetic field might be considered as a supplementary treatment method.

Acknowledgements: This study was supported by Coordination Unit of Selcuk University Scientific Research Projects (Project number: 15202023).

Research funding: This research was supported by Coordination Unit of Selcuk University Scientific Research Projects (Project number: 15202023).

Author contributions: All authors have accepted responsibility for the entire content of this manuscript and approved its submission. 
Conflict of interest: The authors have declared that there is no conflict of interest.

Informed consent: Informed consent was obtained from all individuals included in this study.

Ethical approval: The local Institutional Review Board deemed the study exempt from review.

\section{References}

1. Chien SY, Wu YC, Chung JG, Yang JS, Lu HF, Tsou MF, et al. Quercetin-induced apoptosis acts through mitochondrial- and caspase-3-dependent pathways in human breast cancer MDA-MB-231 cells. Hum Exp Toxicol 2009;28:493-503.

2. Choi EJ. Hesperetin induced G1-phase cell cycle arrest in human breast cancer MCF-7 cells: involvement of CDK4 and p21. Nutr Canc 2007;59:115-9.

3. Choi EJ, Bae SM, Ahn WS. Antiproliferative effects of quercetin through cell cycle arrest and apoptosis in human breast cancer MDA-MB-453 cells. Arch Pharm Res 2008;31:1281-5.

4. Ye L, Chan FL, Chen S, Leung LK. The citrus flavonone hesperetin inhibits growth of aromatase-expressing MCF-7 tumor in ovariectomized athymic mice. J Nutr Biochem 2012;23:1230-7.

5. Shirzad M, Heidarian E, Beshkar P, Gholami-Arjenaki M. Biological effects of hesperetin on interleukin-6/phosphorylated signal transducer and activator of transcription 3 pathway signaling in prostate cancer PC3 cells. Pharmacogn Res 2017;9: 188-94.

6. Turati F, Carioli G, Bravi F, Ferraroni M, Serraino D, Montella M, et al. Mediterranean diet and breast cancer risk. Nutrients 2018; 10:326.

7. Parhiz H, Roohbakhsh A, Soltani F, Rezaee R, Iranshahi M. Antioxidant and anti-inflammatory properties of the citrus flavonoids hesperidin and hesperetin: an updated review of their molecular mechanisms and experimental models. Phytother Res 2015;29:323-31.

8. Roohbakhsh A, Parhiz H, Soltani F, Rezaee R, Iranshahi M. Molecular mechanisms behind the biological effects of hesperidin and hesperetin for the prevention of cancer and cardiovascular diseases. Life Sci 2015;1:64-74.

9. Gibellini L, Pinti M, Nasi M. Quercetin and cancer chemoprevention. Evidence-based complementary and alternative medicine. eCAM 2011;2011:591356.

10. Zhang M, Swarts SG, Yin L, Liu C, TianY, Cao Y, et al. Antioxidant properties of quercetin. Oxyg Trans Tissue 2011;701:283-9.

11. Ozturk B, Durak ZE, Buber S, Kocaoglu EH. Effect of static magnetic field on oxidant/antioxidant parameters in cancerous and noncancerous human gastric tissues. Scientifica 2016;2016: 8608462

12. Ghodbane S, Lahbib A, Sakly M, Abdelmelek H. Bioeffects of static magnetic fields: oxidative stress, genotoxic effects, and cancer studies. BioMed Res Int 2013;2013:602987.

13. Sun RG, Chen WF, Qi H, Zhang K, Bu T, Liu Y, et al. Biologic effects of SMF and paclitaxel on K562 human leukemia cells. Gen Physiol Biophys 2012;31:1-10.

14. Aljarrah K, Mhaidat NM, Al-Akhras MA, Aldaher AN, Albiss B, Aledealat K, et al. Magnetic nanoparticles sensitize MCF-7 breast cancer cells to doxorubicin-induced apoptosis. World J Surg Oncol 2012;10:62.

15. Li J, Ma Y, Li N, Cao Y, Zhu Y. Natural static magnetic field-induced apoptosis in liver cancer cell. Electromagn Biol Med 2014;33: 47-50.

16. Buemi M, Marino D, Di Pasquale G, Loccari F, Senatore M, Aloisi C, et al. Cell proliferation/cell death balance in renal cell cultures after exposure to a static magnetic field. Nephron 2001;87: 269-73.

17. Chionna A, Tenuzzo B, Panzarini E, Dwikat MB, Abbro L, Dini L. Time dependent modifications of Hep $\mathrm{G} 2$ cells during exposure to static magnetic fields. Bioelectromagnetics 2005;26:275-86.

18. Zafari J, Javani Jouni F, Abdolmaleki P, Jalali A, Khodayar MJ. Investigation on the effect of static magnetic field up to $30 \mathrm{mT}$ on viability percent, proliferation rate and $\mathrm{IC}_{50}$ of HeLa and fibroblast cells. Electromagn Biol Med 2015;34:216-20.

19. Vergallo C, Ahmadi M, Mobasheri H, Dini L. Impact of inhomogeneous static magnetic field (31.7-232.0 mT) exposure on human neuroblastoma SH-SY5Y cells during cisplatin administration. PloS One 2014;9:e113530.

20. Chen WT, Lin GB, Lin SH, Lu CH, Hsieh CH, Ma BL, et al. Static magnetic field enhances the anticancer efficacy of capsaicin on HepG2 cells via capsaicin receptor TRPV1. PloS One 2018;13: e0191078.

21. Pacini S, Aterini S, Pacini P, Ruggiero C, Gulisano M, Ruggiero M. Influence of static magnetic field on the antiproliferative effects of vitamin D on human breast cancer cells. Oncol Res 1999;11: 265-71.

22. Aldinucci C, Garcia JB, Palmi M, Sgaragli G, Benocci A, Meini A, et al. The effect of strong static magnetic field on lymphocytes. Bioelectromagnetics 2003;24:109-17.

23. Miyakoshi J. Effects of static magnetic fields at the cellular level. Prog Biophys Mol Biol 2005;87:213-23.

24. Tenuzzo B, Vergallo C, Dini L. Effect of $6 \mathrm{mT}$ static magnetic field on the bcl-2, bax, p53 and hsp70 expression in freshly isolated and in vitro aged human lymphocytes. Tissue Cell 2009;41: 169-79.

25. Tavasoli Z, Abdolmaleki P, Mowla SJ, Ghanati F, Sabet A. Investigation of the effects of static magnetic field on apoptosis in bone marrow stem cells of rat. Environmentalist 2009;29: 220-4.

26. Tatarov I, Panda A, Petkov D, Kolappaswamy K, Thompson K, Kavirayani A, et al. Effect of magnetic fields on tumor growth and viability. Comp Med 2011;61:339-45.

27. Lai H, Singh NP. Magnetic-field-induced DNA strand breaks in brain cells of the rat. Environ Health Perspect 2004;112:687-94.

28. Tofani S, Barone D, Cintorino M, Margherita de Santi M, Ferrara A, Orlassino R, et al. Static and ELF magnetic fields induce tumor growth inhibition and apoptosis. Bioelectromagnetics 2001;22: 419-28.

29. Wiskirchen J, Greonewealler EF, Heinzelmann F, Kehlbach R, Rodegerdts $\mathrm{E}$, Wittau $\mathrm{M}$, et al. Human fetal lung fibroblasts: in vitro study of repetitive magnetic field exposure at $0.2,1.0$, and 1.5 T 1. Radiology 2000;215:858-62.

30. Sakurai H, Okuno K, Kubo A, Nakamura K, Shoda M. Effect of a 7-tesla homogeneous magnetic field on mammalian cells. Bioelectrochem Bioenerg 1999;49:57-63.

31. Teodori L, Geohde W, Valente MG, Tagliaferri F, Coletti D, Perniconi B, et al. Static magnetic fields affect calcium fluxes and 
inhibit stress-induced apoptosis in human glioblastoma cells. Cytometry 2002;49:143-9.

32. Onodera H, Jin Z, Chida S, Suzuki Y, Tago H, Itoyama Y. Effects of 10-T static magnetic field on human peripheral blood immune cells. Radiat Res 2003;159:775-9.

33. Pacini S, Gulisano M, Peruzzi B, Sgambati E, Gheri G, Gheri BS, et al. Effects of $0.2 \mathrm{~T}$ static magnetic field on human skin fibroblasts. Canc Detect Prev 2003;27:327-32.

34. Sghaiera MB, Skandrani I, Nasra N, Francac MGD, ChekirGhediraa L, Ghediraa K. Flavonoids and sesquiterpenes from Tecurium ramosissimum promote antiproliferation of human cancer cells and enhance antioxidant activity: a structure-activity relationship study. Environ Toxicol Pharmacol 2011;32:336-48.

35. Aggarwal V, Tuli HS, Thakral F, Singhal P, Aggarwal D, Srivastava $S$, et al. Molecular mechanisms of action of hesperidin in cancer: recent trends and advancements. Exp Biol Med 2020;245: 486-97.

36. Kashyap D, Mittal S, Sak K, Singhal P, Tuli HS. Molecular mechanisms of action of quercetin in cancer: recent advances. Tumor Biol 2016;37:12927-39.

37. Hashemzae M, Far AD, Yari A, Heravi RE, Tabrizian K, Taghdisi SM, et al. Anticancer and apoptosis-inducing effects of quercetin in vitro and in vivo. Oncol Rep 2017;38:819-28.

38. Florea AM, Büsselberg D. Cisplatin as an anti-tumor drug: cellular mechanisms of activity, drug resistance and induced side effects. Cancers 2011;3:1351-71.

39. Marcuzzi A, Tricarico PM, Piscianz E, Kleiner G, Brumatti LV, Crovella S. Lovastatin induces apoptosis through the mitochondrial pathway in an undifferentiated SH-SY5Y neuroblastoma cell line. Cell Death Dis 2013;4:e585. 